\title{
Association of some hemostasis and endothelial dysfunction factors with probability of presence of vulnerable atherosclerotic plaques in patients with coronary atherosclerosis
}

\author{
Yu. I. Ragino ${ }^{1 *}$, E. V. Striukova ${ }^{*}$ (D, I. S. Murashov², Ya. V. Polonskaya ${ }^{1}$, A. M. Volkov², A. V. Kurguzov², \\ A. M. Chernjavskii ${ }^{2}$ and E. V. Kashtanova ${ }^{1}$
}

\begin{abstract}
Objective: The study was dedicated to investigation of some hemostasis and endothelial dysfunction factors association with probability of presence of vulnerable atherosclerotic plaques in coronary arteries in men with atherosclerosis.

Results: The blood levels of factor VII, factor XII and MCP-1 were higher, and concentration of SVCAM-1 lower in men with vulnerable atherosclerotic plaques in the coronary arteries, compared to men who had stable plaques. Have been revealed correlation links between the blood levels of factor II, factor XII, MCP-1 and the presence of vulnerable atherosclerotic plaques in the coronary arteries. Results of logistic regression analysis showed that the relative risk of present of vulnerable atherosclerotic plaques in the coronary arteries is associated with an elevated blood level of factor XII and MCP-1.
\end{abstract}

Keywords: Factors of hemostasis, Factors of endothelial dysfunction, Factor XII, Monocyte chemoattractant protein 1, Stable and vulnerable atherosclerotic plaques in coronary arteries, Relative risk of present of vulnerable atherosclerotic plaques

\section{Introduction}

Cardiovascular diseases are one of the main causes of mortality in Russia and in the world. The prevalence of ACS also remains extremely high. Initiation of the clinical manifestations of ACS is an erosion or destruction of the endothelium at the site of ulceration/destruction of vulnerable atherosclerotic plaque cover and subsequent thrombus formation and artery occlusion, ischemia and necrosis of the myocardium. Stable plaque is characterized by a thick cover, homogeneous lipid core, the

\footnotetext{
*Correspondence: ragino@mail.ru; stryukova.j@mail.rutel

${ }^{1}$ Research Institute of Internal and Preventive Medicine-Branch

of the Institute of Cytology and Genetics, Siberian Branch of Russian

Academy of Sciences, st.B.Bogatkova 175/1, Novosibirsk 630089, Russia

Full list of author information is available at the end of the article
}

absence of inflammatory changes, and vulnerable by thin cover, or section of thinned cover with focal destruction of the endothelium, the inflammatory cell infiltration, and loose lipid core with areas of necrosis $[1,2]$.

The endothelial dysfunction and oxidative changes of lipoproteins are known to play an important role at the initial stage of atherosclerotic plaque formation, while at the stage of vulnerable plaque formation the activity of inflammatory and destructive processes is pronounced [1, 3-5].

Dysfunction and destruction of endothelium lead to increased secretion of chemoattractants and adhesion molecules, release of endothelin-1, Willebrand factor in blood, decrease of synthesis and secretion of NO. Disorders of hemostasis are known to accompany almost all 
stages of atherosclerotic plaque formation. Components of the hemostatic system not only participate in thrombosis of the affected areas of blood vessels, but also can affect the process of formation and progression of atherosclerotic stenosis $[5,6]$.

In recent years, many studies have been carried out to find and study various pathogenetic biomarkers of coronary atherosclerosis and its complications, especially ACS [7-9].

Purpose of this study was to investigate association of some hemostasis (factor II, factor VII, factor XII, antithrombin III) and endothelial dysfunction (endothelin 1, MCP-1, adhesion molecules SVCAM-1, ADMA, homocysteine, PAI-1) factors/biomarkers with probability of presence of vulnerable atherosclerotic plaques in men with coronary atherosclerosis.

\section{Main text}

\section{Research methods}

The study was conducted in the framework of combined scientific research of Research Institute of Internal and Preventive Medicine-Branch of the Institute of Cytology and Genetics, Siberian Branch of Russian Academy of Sciences and The Federal State Budgetary Institution "National Medical Research Center named after academician E.N. Meshalkin" of the Ministry of Health of the Russian Federation.

The study included 117 men 39-72 years of age with coronary angiographic verified coronary atherosclerosis admitted to the Clinic of the FSBI "National Medical Research Center named academician E.N. Meshalkin" of the Ministry of Health of the Russian Federation on coronary bypass surgery, which during surgery for intraoperative indications was performed endarterectomy from coronary artery/arteries. Exclusion criteria were ACS less than 6 month ago, acute inflammatory conditions, exacerbation of chronic inflammatory diseases, active liver diseases, chronic renal disease, and cancers. Material of endarterectomy containing the intima/media of the artery was transversely divided into fragments, containing atherosclerotic plaque for histological studies. Histological analysis of fragments of the intima/media of the coronary arteries was carried out on a binocular microscope Axiostar Plus (C. Zeiss) with a digital photo output. Stable and vulnerable atherosclerotic plaques differentiated according to the criteria described above [2]. According to the histological conclusion, 54 men (46\%) had only stable atherosclerotic plaques in coronary arteries (CA), and 63 men (54\%) also had vulnerable plaques in $\mathrm{CA}$ along with stable plaques. According to this criterion, all examined patients were divided into two groups.

For biochemical research before coronary artery bypass surgery all the men one-shot after an overnight fast were carried out blood sampling from a vein to obtain plasma and serum. Following hemostasis factors: factor II, factor VII, factor XII, and antithrombin III in the blood plasma were determined by ELISAs method (test system AssayPro). Following endothelial dysfunction factors: endothelin 1 (Biomedica), MCP-1 (Bender Medsystems), sVCAM-1 (Biosource), ADMA (Immunodiagnost), homocysteine (Ahis-Shield), and PAI-1 (Technoclone) were determined by ELISAs method also.

Statistical processing of the results was carried out in the licensed version of SPSS for Windows with the use of correlation, logistic regression and one-way ANOVA analyses using The Dunnet criteria for multiple comparisons.

\section{The results of the study}

According to Table 1, no statistically significant differences were found in the clinical characteristics of the two groups of men (without and with vulnerable atherosclerotic plaques).

In patients with vulnerable atherosclerotic plaques in coronary arteries, plasma levels of factor VII and factor XII (Hageman factor) were 1.4 and 1.4 times higher, respectively $(\mathrm{p}<0.05)$, compared with men without vulnerable atherosclerotic plaques in coronary arteries (Table 2). There were no differences between the two groups of men in plasma levels of factor II and antithrombin III.

In men with vulnerable atherosclerotic plaques in coronary arteries, serum levels of MCP-1 was 1.8 times higher $(p<0.05)$ and concentration of sVCAM-1 was 1.4 times lower $(\mathrm{p}<0.05)$ compared with men without vulnerable atherosclerotic plaques in coronary arteries (Table 2). There was no difference between two groups of men in other factors of endothelial dysfunction plasma levels.

Conducted correlation analysis of the studied hemostasis and endothelial dysfunction factors was revealed strong positive correlation links between the blood levels of factor II, factor XII, MCP-1 and the presence of vulnerable atherosclerotic plaques in the coronary arteries $(\mathrm{r}=0.275, \mathrm{r}=0.359$ and $\mathrm{r}=0.397, \mathrm{p}<0.05$, respectively).

Multifactorial logistic regression analysis (Table 3). showed that the relative risk of the presence of vulnerable atherosclerotic plaques in the coronary arteries is associated with an increased levels of factor XII $(\mathrm{OR}=1.017$, 95\% CI 1.000-1.049, $\mathrm{p}=0.025)$ and MCP-1 $(\mathrm{OR}=1.019$, $95 \%$ CI $1.002-1.055, \mathrm{p}=0.001$ ) only.

\section{Discussion}

On the 1st stage of our investigation we revealed increase of factor VII and XII levels in patients with vulnerable plaques reflecting the intrinsic and extrinsic coagulation pathway. Extrinsic coagulation pathway is known to be 
Table 1 Clinical characteristics of patients

\begin{tabular}{|c|c|c|c|}
\hline Parameter & $\begin{array}{l}\text { Men }(n=54) \text { with stable plaques } \\
\text { in the coronary arteries }\end{array}$ & $\begin{array}{l}\text { Men }(n=63) \text { with vulnerable plaques } \\
\text { in the coronary arteries }\end{array}$ & $p$ \\
\hline Age, years & $60.82 \pm 7.01$ & $59.71 \pm 8.69$ & 0.398 \\
\hline Systolic blood pressure & $141.05 \pm 16.44$ & $135.68 \pm 15.0$ & 0.108 \\
\hline Diastolic blood pressure & $86.22 \pm 9.51$ & $82.74 \pm 9.75$ & 0.920 \\
\hline Pulse rate & $67.98 \pm 6.11$ & $71.24 \pm 7.07$ & 0.280 \\
\hline History of Ml & $71.4 \%$ & $76.4 \%$ & 0.582 \\
\hline History of angina pectoris & $100 \%$ & $100 \%$ & 0.403 \\
\hline IFC & 0 & 0 & \\
\hline$\| F C$ & $14.3 \%$ & $12.7 \%$ & \\
\hline III FC & $69.0 \%$ & $78.2 \%$ & \\
\hline IVFC & $16.7 \%$ & $9.1 \%$ & \\
\hline Essential hypertension & $83.3 \%$ & $87.1 \%$ & 0.384 \\
\hline Ist & 0 & $3.7 \%$ & \\
\hline Ilst & $11.9 \%$ & $5.6 \%$ & \\
\hline Illst & $71.4 \%$ & $77.8 \%$ & \\
\hline Chronic heart failure & $97.6 \%$ & $100 \%$ & 0.439 \\
\hline Ist & $35.7 \%$ & $42.6 \%$ & \\
\hline Ilst & $61.9 \%$ & $53.6 \%$ & \\
\hline Illst & 0 & $1.9 \%$ & \\
\hline IVst & 0 & $1.9 \%$ & \\
\hline History of diabetes type 2 & $11.9 \%$ & $27.3 \%$ & 0.064 \\
\hline Overweight (BMI 25-29.9 kg/m²) & $34.1 \%$ & $46.3 \%$ & 0.440 \\
\hline Obesity (BMI $\geq 30 \mathrm{~kg} / \mathrm{m}^{2}$ ) & $48.8 \%$ & $42.6 \%$ & 0.764 \\
\hline Obesity, 1 degree 30-34.9 & $78.9 \%$ & $82.6 \%$ & \\
\hline Obesity, 2 degree 35-39.9 & $21.1 \%$ & $17.4 \%$ & \\
\hline Obesity, 3 degree $\geq 40$ & 0 & 0 & \\
\hline Smoking & $26.2 \%$ & $12.7 \%$ & 0.077 \\
\hline History of hyperlipidemia & $76.2 \%$ & $65.5 \%$ & 0.252 \\
\hline $\begin{array}{l}\text { Multivascular atherosclerotic lesion of coronary } \\
\text { arteries (more than two vessels) }\end{array}$ & $92.1 \%$ & $89.6 \%$ & 0.689 \\
\hline
\end{tabular}

Table 2 Factors of hemostasis and endothelial dysfunction in men with coronary atherosclerosis $(M \pm \sigma)$

\begin{tabular}{|c|c|c|c|}
\hline $\begin{array}{l}\text { Factors of hemostasis and endothelial } \\
\text { dysfunction in the blood }\end{array}$ & $\begin{array}{l}\text { Men }(n=54) \text { with stable plaques } \\
\text { in the coronary arteries }\end{array}$ & $\begin{array}{l}\text { Men }(n=63) \text { with vulnerable plaques } \\
\text { in the coronary arteries }\end{array}$ & $p$ \\
\hline Factor $\|, \mu \mathrm{g} / \mathrm{ml}$ & $252.1 \pm 50.9$ & $260.1 \pm 58.9$ & 0.474 \\
\hline Factor VIl, ng/ml & $422.0 \pm 147.5$ & $590.1 \pm 150.1^{*}$ & 0.016 \\
\hline Factor XII, $\mu \mathrm{g} / \mathrm{ml}$ & $84.8 \pm 58.1$ & $119.9 \pm 55.2^{*}$ & 0.010 \\
\hline Antithrombin III, $\mu \mathrm{g} / \mathrm{ml}$ & $610.9 \pm 165.5$ & $600.4 \pm 209.6$ & 0.851 \\
\hline Homocystein, $\mu \mathrm{mol} / \mathrm{l}$ & $18.2 \pm 5.2$ & $18.4 \pm 8.1$ & 0.626 \\
\hline $\mathrm{MCP}-1, \mathrm{pg} / \mathrm{ml}$ & $525.7 \pm 188.8$ & $956.8 \pm 501.8^{*}$ & 0.015 \\
\hline Endothelin-1, pmol// & $0.8 \pm 0.6$ & $1.3 \pm 0.6$ & 0.844 \\
\hline ADMA, $\mu \mathrm{mol} / \mathrm{l}$ & $1.4 \pm 0.5$ & $1.4 \pm 0.7$ & 0.821 \\
\hline $\mathrm{PAl}-1, \mathrm{ng} / \mathrm{ml}$ & $397.5 \pm 129.3$ & $399.8 \pm 136.5$ & 0.855 \\
\hline sVCAM-1, ng/ml & $1017.6 \pm 521.8$ & $716.5 \pm 345.6^{*}$ & 0.025 \\
\hline
\end{tabular}

${ }^{*} p<0.05$ 
Table 3 Logistic regression analysis of the relative risk of unstable atherosclerotic plaques

\begin{tabular}{lllll}
\hline $\begin{array}{l}\text { Factors of hemostasis } \\
\text { and endothelial } \\
\text { dysfunction }\end{array}$ & OR & \multicolumn{2}{l}{$\mathbf{9 5 . 0 \%} \mathbf{C l}$} & $\mathbf{p}$ \\
\cline { 3 - 4 } & & Lower & Higher & \\
\hline Factor II & 1.002 & 0.991 & 1.008 & 0.856 \\
Factor VII & 1.000 & 1.000 & 1.004 & 0.765 \\
Factor XII & 1.017 & 1.000 & 1.049 & 0.025 \\
Antithrombin III & 1.000 & 0.994 & 1.003 & 0.854 \\
Homocystein & 0.799 & 0.701 & 1.027 & 0.353 \\
MCP-1 & 1.019 & 1.002 & 1.055 & 0.001 \\
Endothelin-1 & 1.481 & 0.744 & 3.004 & 0.376 \\
ADMA & 0.989 & 0.889 & 1.025 & 0.199 \\
PAI-1 & 0.997 & 0.981 & 1.006 & 0.487 \\
SVCAM-1 & 0.991 & 0.868 & 1.001 & 0.225 \\
\hline
\end{tabular}

associated with formation of the of tissue factor-circulating factor VII complex participating in such proatherogenic processes as migration and proliferation of vascular smooth muscle cells, inflammation and angiogenesis. The results obtained are in line with other investigations which show association between factor VII activity and cardiovascular diseases [10].

Further analysis of obtained data indicated association of vulnerable plaques presence in coronary arteries with factor XII which take part in two main biological processes-hemocoagulation and formation of kinins, active inflammation mediator [11]. Also factor XII is converging point between processes of inflammation and coagulation [12, 13]. Factor XII activate intrinsic coagulation pathway which starts upon appearing of negative charged surfaces on the surface of endothelium which can be observed in destabilization of the plaque. It could explain revealed associations between Hageman factor and relative risk of vulnerable atherosclerotic plaques presence in coronary arteries. The data obtained are in line with the Kuijpers and co-authors [14] results who have found that the accumulation of factor XII on the external surface of blood clots can regulate the pathological process of thrombosis on the surface of atherosclerotic plaques complicated by rupture. Close affinity between coagulation system and atherosclerosis is proved by investigations that show presence of coagulation proteins in atherosclerotic plaques [15].

Analysis of the data obtained showed association of vulnerable atherosclerotic plaques presence in coronary arteries with increased level of MCP-1. MCP-1 ins not only chemoattractant that provide migration and extravasation of mononuclear cells in focus of inflammation but also inflammation mediator activating in addition resident cells. Oxygenized low-density lipoproteins are known to increase concentration of RNA chemokine MCP-1 which increase leucocytes migration into vascular cell and therefore cause destruction of atherosclerotic plaque surface structures. It could explain revealed association between MCP-1 and relative risk of vulnerable atherosclerotic plaques presence in coronary arteries. Our results are in line with our earlier results of MCP-1 examination immediate in atherosclerotic focuses. MCP-1 level was the highest in vulnerable atherosclerotic plaques [16]. Our results do not contradict the data of other researchers who consider that level of MCP-1 in atherosclerotic plaques, including those with calcinosis, is associated with instability of the plaque and that increased levels of MCP-1 in blood is key for identification of unstable plaques presence in patients with atherosclerosis with a high probability and connected with myocardial infarction development $[13,17,18]$.

\section{Conclusion}

Our results indicate that increased blood levels of the Hageman factor and MCP-1 may be a new potential biomarkers of probability of vulnerable atherosclerotic plaques presence in the coronary arteries in men with severe coronary atherosclerosis.

\section{Limitations}

This study is pilot and is limited to a small sample of men with verified coronary atherosclerosis as $97 \%$ of patients admitted on coronary bypass surgery were men. The recruitment of women takes a long time and will be analyzed in the future. Further research will allow to determine the range of threshold values, allowing to predict the presence of the atherosclerotic process destabilization.

\section{Abbreviations}

MCP-1: monocytic chemotactic protein-1; sVCAM-1: soluble vascular cell adhesion molecule 1; ACS: acute coronary syndrome; NO: nitric oxide; ADMA: asymmetric dimethylarginine; PAI-1: plasminogen activator inhibitor-1.

\section{Acknowledgements}

Not applicable.

\section{Authors' contributions}

YIR conceived and designed the study. ISM, AMV, AVK, AMC performed the operation and took samples. EVS, YVP, EVK conducted biochemical analysis as well as were involved in acquisition, analysis and interpretation of the data and writing the manuscript. All authors read and approved the final manuscript.

\section{Funding}

The study was performed in the framework of the budget theme of the State assignment № 0324-2018-0001, and with the financial support of RFBR Grant No. 19-015-00055a. The funding body had no role in the design of the study, data collection, analysis, interpretation of data and in writing the manuscript. 


\section{Availability of data and materials}

The datasets generated and/or analysed during the current study are not publicly available because they are part of a larger dataset which is being reported separately, but are available from the corresponding author on reasonable request.

\section{Ethics approval and consent to participate}

The study was approved by the Ethics committee of Research Institute of Internal and Preventive Medicine-Branch of the Institute of Cytology and Genetics and by the Ethics committee of The Federal State Budgetary Institution "National Medical Research Center named after academician E.N. Meshalkin "of the Ministry of Health of the Russian Federation. The data and samples were collected after written informed consent obtained from all study participants.

\section{Consent for publication}

Not applicable.

\section{Competing interests}

The authors declare that they have no competing interests.

\section{Author details}

${ }^{1}$ Research Institute of Internal and Preventive Medicine-Branch of the Institute of Cytology and Genetics, Siberian Branch of Russian Academy of Sciences, st.B.Bogatkova 175/1, Novosibirsk 630089, Russia. ${ }^{2}$ The Federal State Budgetary Institution "National Medical Research Center named after Academician E.N. Meshalkin" of the Ministry of Health of the Russian Federation, Rechkunovskaya 15, Novosibirsk 630055, Russia.

Received: 27 March 2019 Accepted: 5 June 2019

Published online: 13 June 2019

\section{References}

1. Shah PK. Cellelar and molecular mechanisms of plaque rupture. In: Khachigian LM, editor. High-risk atherosclerotic plaques: mechanisms, imaging, models, and therapy. New York: CRC Press; 2005. p. 1-19.

2. Waksman R, Seruys PW. Handbook of the vulnerable plaque. London: CRC Press; 2004. p. 1-48

3. Yang X, Li Y, Li Y, Ren X, Zhang X, Hu D, Gao Y, Xing Y, Shang H. Oxidative stress-mediated atherosclerosis: mechanisms and therapies. Front Physiol. 2017:8:600. https://doi.org/10.3389/fphys.2017.00600.

4. Virmani R, Burke AP, Farb A, Kolodgie FD. Pathology of the vulnerable plaque. J Am Coll Cardiol. 2006:47(8 Suppl):C13-C1818.

5. Niccoli G, Liuzzo G, Montone RA, Crea F. Advances in mechanisms, imaging and management of the unstable plaque. Atherosclerosis. 2014;233(2):467-77.
6. Fishbein MC. The vulnerable and unstable atherosclerotic plaque. Cardiovasc Pathol. 2010;19(1):6-11.

7. Lu H, Daugherty A. Atherosclerosis. Arterioscler Thromb Vasc Biol. 2015;35(3):485-91. https://doi.org/10.1161/ATVBAHA.115.305380.

8. Jenny NC, Olson NC, Allison MA, Rifkin DE, Daniels LB, et al. Multi-ethnic study of atherosclerosis: biomarkers of key biological pathways in cardiovascular disease. Glob Heart. 2016;11(3):327-36.

9. Koenig W, Khuseyinova N. Biomarkers of atherosclerotic plaque instability and rupture. Arterioscler Thromb Vasc Biol. 2007:27:15-26.

10. Cirillo P, Cali G, Golino P, et al. Tissue factor binding of activated factor VII triggers smooth muscle cell proliferation via extracellular signal-regulated kinase activation. Circulation. 2004;109(23):2911-6.

11. Renne T, Schmaier AH, Nickel KF, et al. In vivo roles of factor XII. Blood. 2012;120(22):4296-303.

12. Cho KY, Miyoshi H, Kuroda S, Yasuda H, Kamiyama K, Nakagawara J, Takigami M, Kondo T, Atsumi T. The phenotype of infiltrating macrophages influences arteriosclerotic plaque vulnerability in the carotid artery. J Stroke Cerebrovasc Dis. 2013;22(7):910-8. https://doi.org/10.1016/j.jstro kecerebrovasdis.2012.11.020.

13. Hoogeveen RC, Morrison A, Boerwinkle E, Miles JS, Rhodes CE, Sharrett AR, Ballantyne CM. PlasmaMCP-1 level and risk for peripheral arterial disease and incident coronary heart disease: atherosclerosis risk in communities study. Atherosclerosis. 2005;183(2):301-7.

14. Kuijpers MJ, van der Meijden PE, Feijge MA, Mattheij NJ, May F, GoversRiemslag J, Cosemans JM. Factor XII regulates the pathological process of thrombus formation on ruptured plaques. Arterioscler Thromb Vasc Biol. 2014;34(8):1674-80.

15. Borissoff Jl, et al. Early atherosclerosis exhibits an enhanced procoagulant state. Circulation. 2010;122(8):821.

16. Polonskaya YV, Kashtanova EV, Striukova EV, Volkov AM, Murashov IS, Chernyavsky AM, Ragino YI. Dynamics of changes in concentration of inflammatory and destructive biomarkers at various stages of atherosclerotic plaque development. Cardiac Sci Res J. 2018;1(2):1-5.

17. Deo R, Khera A, McGuire DK, Murphy SA, MeoNetoJde P, Morrow DA, de Lemos JA. Association among plasma levels of monocyte chemoattractant protein-1, traditional cardiovascular risk factors, and subclinical atherosclerosis. J Am Coll Cardiol. 2004;44(9):1812-8.

18. Ma Y, Yabluchanskiy A, Hall ME, Lindsey ML. Using plasmamatrix metalloproteinase-9 and monocyte chemoattractant protein-1 to predict future cardiovascular events in subjects with carotid atherosclerosis. Atherosclerosis. 2014;232(1):231-3. https://doi.org/10.1016/j.atheroscle rosis.2013.09.013.

\section{Publisher's Note}

Springer Nature remains neutral with regard to jurisdictional claims in published maps and institutional affiliations.

Ready to submit your research? Choose BMC and benefit from:

- fast, convenient online submission

- thorough peer review by experienced researchers in your field

- rapid publication on acceptance

- support for research data, including large and complex data types

- gold Open Access which fosters wider collaboration and increased citations

- maximum visibility for your research: over 100M website views per year

At BMC, research is always in progress.

Learn more biomedcentral.com/submissions 